\title{
Brocados e ouropéis, gemas e cristais
}

Luiz Nazario I UFMG

\begin{abstract}
Resumo: A crítica literária nega ou minimiza a existência de uma literatura surrealista brasileira, embora a literatura modernista seja uma releitura das vanguardas européias. Por seu lado, para ressaltar o próprio nacionalismo, os modernistas renegaram suas fontes européias em prol do folclore nativo. Por isso, em seu internacionalismo militante, nossos surrealistas desprezaram os modernistas (nossos primeiros surrealistas) e não reivindicaram ativamente (diferentemente do que fizeram os surrealistas europeus) a tradição revolucionária do simbolismo. Para recuperar o modernismo para o surrealismo, deve-se redimensioná-lo na tradição das vanguardas européias, operação que se completa com a redescoberta de nosso simbolismo como sua fonte mais pura.

Palavras-chave: modernismo, surrealismo, simbolismo, vanguardas, ideologia.
\end{abstract}

Crítico Cláudio Willer observou que o modernismo brasileiro não conseguiu enxergar na tradição literária brasileira seus mais legítimos antecedentes em matéria de transgressão: eles desconheciam ou fingiam desconhecer as obras que no século anterior já haviam realizado os feitos que o modernismo iria propor como novidades. ${ }^{1}$ Na França, o surrealismo, liderado por André Breton, atribuiu grande importância à correia de transmissão da tradição do fantástico e do

1. http://www.revista.agulha.nom.br/ag27willer.htm 
maravilhoso, identificando no simbolismo as raízes da estética surrealista, e recuando mesmo a expressões artísticas e literárias da Idade Média. Repetindo o erro dos modernistas, os surrealistas brasileiros que se reuniram em São Paulo nos anos de 1960 ignoraram seus antecessores (alguns ainda vivos) e mesmo seus contemporâneos de outros estados. E, ainda quando esses autores eram lidos e apreciados, seus "herdeiros" não tentavam aproximar-se deles.

Em diversos escritos, o líder do movimento surrealista brasileiro, Sergio Lima, citou como um marco do "nascimento de uma poesia do maravilhoso no Brasil" o poeta simbolista, filho de escravos, João da Cruz e Sousa (1861-1898), valorizando-o justamente (tal como Breton valorizara Lautréamont) por seu canto negro do Feminino e do Obscuro, ao lado de sua mística da Brancura. A aura de "maldito" do poeta negro, vítima do estigma racial, desprezado na vida e na morte, tendo seu corpo levado à família num vagão de trem que transportava animais, aproxima-o do jovem e rebelde homossexual Arthur Rimbaud. Mas, para além das circunstâncias sociais de opressão às minorias, a poesia e ainda mais a prosa poética de Cruz e Souza possuem tanto vigor; e sua sensibilidade é tão rica de imagens a brotar do inconsciente, que a leitura de "Emparedado", por exemplo, dispensa qualquer comparação e basta para inserir o autor entre os "pais" do surrealismo universal:

[...] Artista! Pode lá isso ser se tu és d'África, tórrida e bárbara, devorada insaciavelmente pelo deserto, tumultuando de matas bravias, arrastada sangrando no lodo das Civilizações despóticas, torvamente amamentada com o leite amargo e venenoso da Angústia! A África arrebatada nos ciclones torvelinhantes das Impiedades supremas, das Blasfêmias absolutas, gemendo, rugindo, bramando no caos feroz, hórrido, das profundas selvas brutas, a sua formidável Dilaceração humana! A África laocoôntica, alma de trevas e de chamas, fecundada no Sol e na Noite, errantemente tempestuosa como a alma espiritualizada e tantálica da Rússia, gerada no Degredo e na Neve - pólo branco e pólo negro da Dor!

$[\ldots]$

Não! Não! Não! Não transporás os pórticos milenários da vasta edificação do Mundo, porque atrás de ti e adiante de ti não sei quantas gerações foram acumulando, acumulando pedra sobre pedra, pedra sobre pedra, que para aí estás agora o verdadeiro emparedado de uma raça. 
Se caminhares para a direita baterás e esbarrarás ansioso, aflito, numa parede horrendamente incomensurável de Egoísmos e Preconceitos! Se caminhares para a esquerda, outra parede, de Ciências e Críticas, mais alta do que a primeira, te mergulhará profundamente no espanto! Se caminhares para frente, ainda nova parede, feita de Despeitos e Impotências, tremenda, de granito, broncamente se elevará ao alto! Se caminhares, enfim, para trás, ah! Ainda, uma derradeira parede, fechando tudo, fechando tudo - horrível! — parede de Imbecilidade e Ignorância, te deixará num frio espasmo de terror absoluto...

E mais pedras, mais pedras se sobreporão às pedras já acumuladas, mais pedras, mais pedras... Pedras destas odiosas, caricatas e fatigantes Civilizações e Sociedades... Mais pedras, mais pedras! E as estranhas paredes hão de subir, - longas, negras, terríficas! Hão de subir, subir, subir mudas, silenciosas, até às Estrelas, deixando-te para sempre perdidamente alucinado e emparedado dentro do teu Sonho...

Num jorro de idéias incandescentes, o "Emparedado" antecipa os grandes temas do surrealismo: da percepção da dimensão convulsiva da Beleza à missão sagrada do poeta como vidente, da pouca realidade que nos é concedida ( mais pouca para um brasileiro da elite, e ainda mais pouca para um filho de escravos no Brasil do século XIX) ao apego irresistível ao mundo do imaginário. E ao surrealismo universal acrescenta Cruz e Souza uma vertente brasileira, na afirmação de orgulho de um Orfeu negro que protesta, muito antes de Aimé Cesaire, ${ }^{3}$ contra a imanência dos determinismos racistas do social-darwinismo. O emparedado abraça a transcendência na direção da pureza da Arte vivida no extremo prazer da consciência de pertencer-lhe e na extrema dor de saber que os administradores do mundo impedirão de sua vida o ansiado reconhecimento desse pertencimento.

Amigo de Cruz e Sousa, a quem este dedicou o belo poema "O sapo humano", o curitibano Emiliano Perneta (1866-1921) publicou seus primeiros poemas em O Dilúculo, de Curitiba, em 1883. Logo se mudou para São Paulo, onde fundou a Folha Literária, com Afonso de Carvalho, Carvalho Mourão e Edmundo Lins, publicou Músicas e Carta à Condessa d'Eu (1888), dirigiu a Vida

2. CRUZ E SOUZA, 1995, p. 672-673.

3. SARTRE, 1968. 
Semanária com Olavo Bilac, e colaborou no Diário Populare na Gazeta de São Paulo. Depois de formar-se bacharel em Direito em 1889, mudou-se para o Rio de Janeiro, lá colaborando em vários periódicos, como a Folha Popular, na qual foram publicadas as primeiras manifestações de nosso simbolismo por B. Lopes, Cruz e Sousa e Oscar Rosas. De volta ao Paraná, criou em 1902 a revista simbolista Victrix. Em 1913 criou o poema-livreto Papilio Innocentia para a ópera do compositor suíço Leo Kessler, baseada no romance Inocência, de Visconde de Taunay. Sua obra poética inclui Ilusão (1911), Pena de Talião (1914) e o póstumo Setembro (1934). Suas Poesias Completas foram publicadas em 1945 . ${ }^{4}$ Uma das maravilhas do simbolismo brasileiro é este estranho soneto de Perneta, que evoca a crescente defasagem entre a consciência e a existência, fonte da eterna angústia que devora aqueles que desejam viver a vida em sua totalidade:

\section{Corre mais que uma vela...}

Corre mais que uma vela, mais depressa, Ainda mais depressa do que o vento, Corre como se fosse a treva espessa Do tenebroso véu do esquecimento.

Eu não sei de corrida igual a essa: São anos e parece que é um momento; Corre, não cessa de correr, não cessa, Corre mais do que a luz e o pensamento... É uma corrida doida essa corrida, Mais furiosa do que a própria vida, Mais veloz que as notícias infernais... Corre mais fatalmente do que a sorte, Corre para a desgraça e para a morte... Mas eu queria que corresse mais!

Também o teatro do estranho personagem gaúcho José Joaquim de Campos Leão, o Qorpo-Santo (1829-1883), deve ser recordado. Criado por volta de 1860, influenciado por peças de circos e operetas italianas apresentadas em Porto Alegre, o Teatro Nonsense de Qorpo-Santo parece antecipar o Teatro Grotesco

4. http://www.jayrus.art.br/index14.html 
de Alfred Jarry. Considerando o automatismo psíquico no qual o autor, numa insônia delirante, compunha suas obras, o crítico Eudinyr Fraga considerou este teatro uma antecipação da dramaturgia do surrealismo. Mas ele também pode ser aproximado do Teatro da Crueldade de Antonin Artaud e mesmo do Teatro do Absurdo de Eugène Ionesco. De qualquer forma, nas suas 17 peças $^{6}$ de feitio e formato inusitados, vertidas no papel em algumas horas, de um só jato, QorpoSanto demonstrou toda sua dissonância em relação à sociedade de seu tempo. Em A separação de dois esposos, ousou abordar o tema tabu da homossexualidade nas "figuras verdadeiramente beckettianas, Tamandaré e Tatu":

TAMANDUÁ: - Tu ainda não sabes a quarta parte [...]! Oh! se tu soubesses.

TATU (agarrando-o e com muito empenho): — Ora, amigo! diz, anda, fala; eu quero ouvir-te.

TAMANDUÁ: - Não! (com aspecto impertinente): Não digo nada. Não quero te fazer saltar ao teto de júbilo.

TATU: - Mau! Ingrato! A gente quer tanto bem a ele; e ele ainda quer ter segredos. Quer ocultar-me cousas que me podem dar prazer.

TAMANDUÁ: - Não digo! Não quero! ( muito zangado, e batendo com as mãos) Estou com raiva.

TATU: - Por que, meu queridinho? (afagando-o) Que te fizeram?

TAMANDUÁ: - Ora por que! Inda pergunta? Não se lembra que por três vezes quis casar carnal e espiritualmente... Com seu primo Eustaquinho;

5. FRAGA, 1988.

6. O hóspede atrevido, ou O brilhante escondido; O marinheiro escritor; Dois irmãos; Duas páginas em branco; Mateus e Mateusa; As relações naturais; Hoje sou um e amanhã outro; Eu sou a vida; eu não sou a morte; A separação de dois esposos; Um marido extremoso ou O pai cuidadoso; Um credor da Fazenda Nacional; Um assovio; Certa entidade em busca de outra; Lanterna de fogo; Um parto; Uma pitada de rapé. Ver: Qorpo-Santo, 2001. Oito peças encontram-se digitalizadas em: <http:// www.biblio.com.br/Templates/qorposanto/molduraobras.htm>.

7. STEGAGNO-PICCHIO, 1997, p. 447. 
e depois (empurrando-o) até com você! E que nem ele, nem você têm querido!? Fazendo assim penar esta alma, este coração!... Esta cabeça!...

TATU: - Ó diabo! Tu estás variando! Quanto ao espírito, nem todos os demônios que habitam por todas as regiões são capazes de nos divorciar, e quanto ao parir... Mais devagar; eu sou homem; (pondo-lhe a mão no ombro) não sou mulher! E tu hás-de saber que é o vício mais danoso que o homem pode praticar!

TAMANDUÁ: Mas que queres? (Ainda com aspecto impertinente.) Apaixonar-me por ti de todos os modos! Paixão da alma! Paixão do corpo! E se tu não quiseres satisfazer este desejo ou loucura... vou... faço... aconteço... pego... levo... (atirando-lhe com as mãos) faço o diabo! (gritando).

TATU: - Pois já que se não contenta com o nosso casamento espiritual somente, sendo ambos homens! Já que quer o imundo e absurdo casamento carnal, declaro-lhe que não sou mais seu sócio (empurrando-o).

TAMANDUÁ (empurrando-o também): - Pois eu também não sou mais seu! (Há a mais renhida luta entre eles em que rompem chapéus; descalçamse; rasgam casacos; e findam a comédia saindo aos gritos.) Fiquemos sem chapéu, sem botas, sem camisa! Mas estamos divorciados carnalmente e espiritualmente. Não! Não! Não! (perto das portas por onde tem de sair; $e$ voltando o rosto para a Cena, com os chapéus ou restos destes levantados): Viva!... Viva!... Viva!...

Na comédia Eu sou a vida; eu não sou a morte, os protagonistas, Linda e Lindo, pensam, falam e agem como surrealistas avant la lettre:

LINDO: - Tu és o diabo! Ninguém pode contigo! És tripa que nunca se enche, por mais que dentro se lhe bote. És vasilha que não chocalha. És... o que eu não quero dizer, porque não quero que se saiba.

LINDA: - Pois já que me fazes comparações tão sublimes, eu também vou te fazer uma de que muito te deves agradar. Sabes qual é, não? Pois eu te digo: és o diabo em figura de homem! És... és... (atirando com as mãos e caminhando de um para outro lado) és... és! és! E então, que mais queres!? Quero comparações mais bonitas; mais finas; delicadas; e elevadas; ao contrário, ficaremos figadais inimigos. Tem entendido Sr. Sultãozinho? Pois se não tiver entendido, entenda! 
LINDO: - Bem. Vou fazer-lhe as mais mimosas que à minha imaginação abundante, crescente, e algumas vezes até demente — ocorrem! Lá vai uma: A Senhora é pêra que não se come!

LINDA: — Essa não presta!

LINDO: (batendo na testa) - É preciso arrancar desta cabeça, ainda que seja com algum gancho de ferro uma comparação que satisfaça a esta mulher; ao contrário é capaz de...

LINDA: - E não se demore muito com as suas reflexões! Quero a comédia.

LINDO: - Qual comédia, nem comédia! O que me comprometi a fazerlhe foi comparação bonita; e não comédia. Espere, portanto. (Torna a bater na cabeça, mais no crânio. À parte:) Já que da testa não sai, vejamos se tiro do crânio! Ah! Sim; agora aparece uma; e que bela; que interessante; que agradável; que bonita; que delicada; que mimosa — é a comparação que vou fazer da Sra. D. Linda! Mesmo tão linda como ela! Tão formosa, como a flor mais mimosa! Tão rica, como a jorrosa bica! Tão fina, como a ignota sina! Tão... tão... tão... Quer mais? Quer melhor? Não lhe dou; não lhe faço; não quero! ( $A$ correr em roda dela:) Não lhe dou; não the faço; não lhe dou; não lhe faço; não quero; não posso; já disse. (Repete duas vezes esta última negativa.)

LINDA: - Este menino é o diabinho em figura humana! Dança, salta, pula, brinca... Faz o diabo! [...] Enfim, é o ente mais extraordinário que meus olhos têm visto, que minhas mãos têm apalpado, que meu coração tem amado!

LINDO: - Senhora: vou-me embora (Voltando-se rapidamente para ela, com aspecto muito triste, e salpicado de indignação:) Vou; vou, sim! Não a quero mais ver; não sou mais seu!

LINDA: (com sentimento) — Cruel! Tirano! Suíço! Lagarto! Bicho feio! Mau! Onde queres ir? Por que não te casas, inda que seja com uma negra quitandeira?

LINDO: — Também eu direi. Cruel! Ingrata! Má! Feia! Por que não te ligas ainda que seja a um preto cangueiro?

(Entra um rapaz todo paramentado, bengala, óculos, etc.) 
O RAPAZ: (para um, e depois para a outra) — Vivam madamas; mais que todos!

LINDO: (pondo-lhe as mãos, e empurrando) - O que quer, pois aquil? Não sabe que esta mulher é minha esposa!?

O RAPAZ: - Dispense, eu não sabia! (Voltando-se para Linda:) Mas Senhora, parece-me...

LINDA: — O que mais?! Não ouviu já ele dizer que sou mulher dele!? O que mais quer agora? Agora fique solteiro, e vá casar com uma enxada! Não quer acreditar que não há direito; que ninguém faz caso de papéis borrados; que isso são letras mortas; que o que serve, o que vale, o que dá direito - é a aquisição da mulher!? Que quem se pega com uma, essa tem, e tudo o que lhe pertence! Sofra agora no isolamento, e na obscuridade! Seja solitário! Viva para Deus! Ou meta-se num convento, se quiser companhia. Não vá mais à reunião de outros homens.

O RAPAZ: (muito admirado) — Esta mulher está doida! Casou comigo o ano passado, foram padrinhos Trico e Trica; e agora fala esta linguagem! Está; está! Não tem dúvida!

Também em Mateus e Mateusa, há diálogos, ações e alusões de incrível atualidade e humor absurdo, incluindo subversivas críticas à corrupção dos políticos e juízes, à inutilidade dos códigos legais e dos sacramentos da igreja:

MATEUS: - [...] minha querida Mateusa [...] confessa-me: Por que não quiseste tu o teu nome de batismo, que te foi posto por teus falecidos Pais?

MATEUSA: - Porque achei muito feio o nome Jônatas que me puseram; e então preferi o de Mateusa, que bem casa com o teu!

MATEUS: - Sempre és mulher! E não sei o que me pareces depois que ficaste velha e rabugenta!

MATEUSA (recuando um pouco): — És bem atrevido! De repente, e quando não esperares, hei de tomar a mais justa vingança das grosserias, das duras afrontas com que costumas insultar-me!

8. http://www.biblio.com.br/Templates/qorposanto/meusouavida.htm 


\section{MATEUS (aproximando-se e ela recuando)}

MATEUSA: - Não se chegue para mim (pondo as mãos na cintura e arregaçando os punhos) que eu não sou mais sua! Não o quero mais! Já tenho outro com quem pretendo viver mais felizes dias!

MATEUS (correndo a abraçá-la apressadamente): — Minha queridinha; minha velhinha! Minha companheirinha de mais de 50 anos (agarrandoa), por quem és, não fujas de mim, do vosso velhinho! E as nossas queridas filhinhas! Que seriam delas, se nós nos separássemos; se tu buscasses, depois de velha e feia, outro marido, ainda que moço e bonito! Que seria de mim? Que seria de ti? Não! Não! Tu jamais me deixarás. (Tanto se abraçam; agarram; pegam, beijam-se, que cai um por cima do outro.) Ai! Que quase quebrei uma perna! Esta velha é o diabo! Sempre mostra que é velha e renga! (Querem erguer-se sem poder.) Isto é o diabo!...

MATEUSA (levantando-se, querendo fazê-lo apressadamente e sem poder, cobrindo as pernas que, com o tombo, ficaram algum tanto descobertas): — É isto, este velho! Pois não querem ver só a cara dele? Parece-me o diabo em figura humana! Estou tonta... Nunca mais, nunca mais hei de aturar este carneiro velho, e já sem guampas! (Ambos levantaram-se muito devagar; a muito custo; e sempre praguejando um contra o outro. Mateusa, fazendo menção ou dando no ar ora com uma, ora com outra mão:) Hei de ir-me embora; hei de ir; hei de ir!

MATEUS: - Não há de ir; não há de ir; não há de ir porque eu não quero que vá! Você é minha mulher; e pelas leis tanto civis como canônicas, tem obrigação de me amar e de me aturar; de comigo viver, até eu me aborrecer! (Bate com um pé.) Há de! Há de! Há de!

MATEUSA: - Não hei de! Não hei de! Não hei de! Quem sabe se eu sou sua escrava!? É muito gracioso, e até atrevido! Querer cercear a minha liberdade! E ainda me fala em Leis da Igreja e civis, como se alguém fizesse caso de papéis borrados! Quem é que se importa hoje com Leis (atirando-lhe com o 'Código Criminal'), Sr. banana! Bem mostra que é filho dum lavrador de Viana! Pegue lá o Código Criminal, traste velho em que os Doutores cospem e escarram todos os dias, como se fosse uma nojenta escarradeira!

MATEUS (espremendo-se todo, abaixa-se levanta o livro e diz à mulher): - Obrigado pelo presente: adivinhou ser cousa de que eu muito 
necessitava! (Mete-o na algibeira. À parte:) Ao menos servirá para algumas vezes servir-me de suas folhas, uma em cada dia que estas tripas (pondo a mão na barriga) me revelarem a necessidade de ir à latrina.

MATEUSA: - Ah! já sabe que isso não vale cousa alguma; e principalmente para as Autoridades - para quem tem dinheiro! Estimo muito; muito; e muito! (Pega em um outro - a 'Constituição do Império'e atira-lhe na cara.)

MATEUS (gritando): - Ai! cuidado quando atirar, Sra. D. Mateusa! Não continuo a aceitar seus presentes, se com eles me quiser quebrar o nariz! (Apalpa este, e diz:) Não partiu, não quebrou, não entortou! (E como o nariz tem parte de cera, fica com ele assaz torto. Ainda não acaba de endireitá-lo, Mateusa atira-lhe com outro de 'História Sagrada', que lhe bate numa orelha postiça, e que por isso com a pancada cai; dizendo-lhe:) Eis o terceiro e último que lhe dou para... os fins que o Sr. quiser aplicar!

Burguês na aparência, casado, habilitado para o magistério, o escritor acreditou-se, ao atingir os 30 anos de idade, ser uma espécie de santo. A família, desacoroçoada, pediu a intervenção judicial de seus bens; a saúde mental do escritor foi avaliada por dois peritos de Porto Alegre, que chegaram a conclusões divergentes. Qorpo-Santo pôs-se então a escrever compulsivamente sua Ensiqlopédia ou seis mezes de buma enfermidade, dividida em nove volumes, na ortografia pouco ortodoxa que inventara, trocando o "q" pelo "c" e o "c" pelo "s". Conseguindo adquirir uma tipografia, imprimiu sua obra recusada pelas editoras num papel barato em apenas um exemplar, entregando essa coleção única a um amigo comerciante. Os volumes permaneceram na biblioteca da família do comerciante até que foram vendidos para sebos. A partir desse momento, um século de silêncio caiu sobre a obra de Qorpo-Santo.

Em 1969, contudo, o estudioso Guilhermino César redescobriu QorpoSanto e organizou a primeira edição de suas peças teatrais. (Notemos, en passant, que a descoberta de Qorpo-Santo também é reivindicada por Aníbal Damasceno e Fausto Fuser). O colecionador Julio Petersen, de Porto Alegre, localizou três volumes da Ensiqlopédia; outro foi doado ao Instituto Histórico gaúcho; três pertencem à família Assis Brasil; dois encontram-se perdidos. Em 1995, a pesquisadora Denise Espírito Santo, depois de dez meses vasculhando sebos e bibliotecas de Porto Alegre, descobriu um exemplar com 537 poemas. Depois de cinco anos de negociações com editoras, a carioca Contra Capa editou os Poemas, com foto 
inédita de Qorpo-Santo na capa. Para Denise, a obra acrescenta à poesia brasileira um estilo novo, em que assuntos triviais e o nonsense dominam os temas, em contraste com as convenções estéticas da época. ' São notáveis, pela temática, seus poemas sobre animais e insetos ou sobre as coisas, como os versos quase dalinianos dedicados às formigas ou às imundícies:

\section{Formiguinha}

Ó minha formiguinha, Deixa essa palhinha, Procura migalhinha, Que é melhor comidinha! $!^{10}$

\section{Imundícies}

As imundícies levam sopapos;

As imundícies vão para o buraco!

As limpezas - dão grande salto;

As limpezas - sobem ao Palco!

Entre outros precursores nacionais do surrealismo, poderíamos citar o maranhense Joaquim de Sousa Andrade, o Sousândrade (1833-1902). Criado na Paris de 1853-1857, onde se doutorou em Letras pela Sorbonne, depois de voltar à pátria e ser abandonado pela mulher, vagou pela América Central e do Sul até fixar-se nos EUA, onde publicou suas Obraspoéticas (1874). Sua obra maior, Guesa errante (1884), redigida ao longo de trinta anos, foi editada na Inglaterra. Retornou ao Brasil na velhice, para lecionar grego num liceu de São Luís do Maranhão, onde, andando pelas ruas de fraque e cartola, perseguido pelos moleques, era tido por excêntrico. Autor de um projeto de instalação, em São Luís, da primeira universidade brasileira, e idealizador da Bandeira do Maranhão, o poeta morreu só, incompreendido e miserável.

A redescoberta de Sousândrade deveu-se a uma série de releituras: a primeira, pelo crítico Fausto Cunha, em artigo pioneiro de 1954; seguiram-se os

9. http://www.secrel.com.br/jpoesia/qsanto.html\#inicio

10. QORPO-SANTO, 2000, p. 39.

11. QORPO-SANTO, 2000, p. 169. 
relatos do jornalista Oswaldino Marques sobre a legenda que circulava em Belém sobre o poeta; as descobertas de Luís Costa Lima, que em 1958 se deparou com um exemplar de O Novo Éden (1893), na Biblioteca do Estado de São Luís, e desencavou com a ajuda de uma estudante de filologia um exemplar de Guesa errante, vindo a encontrar o inédito Harpas de ouro; a aproximação que Edgard Cavalheiro fez em O antropófago do romantismo entre Sousândrade e Oswald de Andrade; finalmente, o ensaio Montagem: Sousândrade (1960-1961), de Augusto e Haroldo de Campos, que compilariam a antologia ReVisão de Sousândrade (1964, revista e ampliada em 1982), acompanhada de ensaios críticos. Durante os anos de 1970, o governo do Estado do Maranhão patrocinou a publicação dos Inéditos de Sousândrade e do Guesa errante, além da biografia escrita pelo norte-americano Frederick Williams; e a tese Tradição e Ruptura: o Guesa de Sousândrade, de Luiza Lobo. ${ }^{12}$

O herói do Guesa errante é um jovem que deve ser sacrificado a Bochica, deus do sol, segundo uma antiga tradição dos índios muíscas da Colômbia, que Sousândrade encontrara em suas leituras de Alexander von Humboldt. O Guesa era um menino de dez anos que deveria repetir o caminho do deus Suna até a idade dos quinze anos, quando seria sacrificado pelos xeques, os sacerdotes. Sousândrade confunde no poema o Guesa-poeta e o Guesa-índio. E assim duplicado, o Guesa-índio-poeta destinado ao sacrifício inicia seu périplo. Resume a historiadora Luciana Stegagno-Picchio os treze cantos do longo poema (inacabado), dotado de uma construção ambiciosa até em seu fragmentarismo de obra aberta:

O primeiro canto parte dos Andes, onde se celebra o culto do sol. Mas, logo depois, a conquista branca degrada o homem do Novo Mundo, e eis que no segundo canto já assistimos à dança lúbrica dos índios decadentes da Amazônia. O Guesa desce na Amazônia, volta ao Maranhão da infância e aí, entre as ruínas da casa natal, define-se o seu destino poético. No peregrinar que a partir desse momento é a sua sorte, ele passa de uma África luxuriante a uma Europa que, no entanto, é sempre o "grande amigo mundo", ao Haiti de Bonaparte, ao México de Montezuma e de Guatemozim: até, no canto X, desembarcar em Nova York. E, às margens do Hudson, no "Inferno de Wall Street", ele adquire noção de sua estranheza para o jovem povo norte-americano. No epílogo, o Guesa, enfermo, voltará à pátria onde um metafórico arco-íris encerrará o poema, sem, contudo, concluí-lo.

12. LOBO, 1979.

13. STEGAGNO-PICCHIO, 1997, p. 222. 
Personagens mitológicos (Tellus, Coelus, Jesus); lendários (Manco Capac, Mama Occlo); literários (Enéas, Odisseu, Orfeu); e históricos (Nabucodonosor, Epicuro, Dante, Santo Inácio, Pizarro, George Washington, Presidente Grant, Hendrick Hudson, Rotschild, Swedenborg, D. Pedro II, general Abreu e Lima, Gonçalves Dias, matemático Gomes de Sousa, além de industriais, financistas e políticos da época) entoam uma sinfonia dodecafônica e multilíngüe (em tupi, quíchua, grego, latim, português, inglês, italiano, espanhol, francês). Passado mítico e passado imaginário, antiguidade e modernidade imbricam-se num espaço-tempo irreal, onde eventos distantes ganham sincronia e quebram a seqüência narrativa para gerar um universo alheio ao devir histórico. A composição precursora não apenas do surrealismo como até do pós-modernismo ancora-se na idéia simbolista de Mallarmé de que o "mundo existe para terminar num livro". No famoso canto X, para escapar dos sacerdotes que desejam imolá-lo, o Guesa refugia-se em Nova York e vivencia o Inferno de Wall Street:

\section{$[\ldots]$}

(Procissão internacional, povo de Israel, Orangianos, Fenianos, Budas, Mórmons, Comunistas, Niilistas, Farricocos, Railroad-Strikers, All-brokers, All-jobbers, All-saints, All-devils, lanternas, música, sensação; Reporters; passa em LONDRES o assassino da RAINHA e, em PARIS, Lot, o fugitivo de SODOMA:)

No Espírito-Santo d'escravos

Há somente um Imperador

No dos livres, verso

Reverso

É tudo coroado Senhor! ${ }^{14}$

$[\ldots]$

— Orfeu, Dante, Eneas, ao inferno

Desceram; o Inca há de subir...

= Ogni sp'ranza lasciate,

Che entrate...

Swedenborg, há mundo porvir?

14. http://planeta.terra.com.br/arte/PopBox/cdsousandrade.htm 
(Xeques surgindo risonhos e disfarçando e disfarçados em Railroadmanagers, Stockjobbers, Pimpbrokers, etc., etc., apregoando:)

— Harlem! Erie! Central! Pennsylvania!

— Milhão! Cem milhões!! Mil milhões!!!

— Young é Grant! Jackson,

Atkinson!

Vanderbilits, Jay Goulds, anões!

(A Voz mal ouvida dentre a trovoada:)

— Fulton's Folly, Codezo's Forgery...

Fraude é o clamor da nação!

Não entendem odes

Railroads;

Paralela Wall-Street à Chattám...

(Corretores continuando:)

— Pygmeus, Brown Brothers! Bennett! Stewart!

Rotschild e o ruivalho d'Astor!!

$=$ Gigantes escravos

Se os cravos

Jorram luz, se finda-se a dor!... ${ }^{15}$

Luiz Costa Lima destacou, na poesia de Sousândrade, "seu extremo sintetismo, suas deformações expressivas, sua tremenda agressividade formalconteudística, suas aglutinações com línguas estrangeiras”; e desvendou alguns significados semi-encobertos pela erudição do autor no esotérico Guesa errantesignificados que nos parecem bastante superficiais:

Os dois primeiros versos (da última estrofe) são formados por frases comuns na América daqueles anos: a loucura de um inventor se punha ao lado da fraude de alguém que só os jornais americanos da época esclareceriam. O segundo verso parece antecipar uma reflexão sobre nossos espertos de hoje. Os versos três e quatro - cuja rima ou se julga imperfeita pela abertura vocálica de 'odes' ou, em solução mais ousada, se ouve mesmo pela discrepância fonética entre a palavra portuguesa

15. STEGAGNO-PICCHIO, 1997, p. 223. 
'odes' e a inglesa 'railroads' - reiteram em nível material e concreto o que afirmava o verso dois. Tudo isso leva à topografia do último verso. Sabe-se pelos mapas daquela New York que Chattam era o nome de uma praça que havia próxima a Wall Street. Mas a acentuação que lhe concede o poeta e a pronúncia que o leitor do português lhe daria não a aproximava de Satã? ${ }^{16}$

A condenação de Sousândrade do inferno de Wall Street é, no fundo, moralista: o surrealismo pós-moderno de sua sensibilidade romântico-simbolista enlouquecida aproxima-o hoje mais da visão de mundo dos terroristas islâmicos que derrubaram o World Trade Center que das vítimas internacionais incineradas no atentado; pelo subtom anti-semita e antiamericano do Guesa errante, seu autor pode hoje ser reivindicado tanto pelos militantes concretistas e surrealistas quanto pelos militantes antiglobalização neonazistas e neo-stalinistas em simbiose com os fundamentalistas islâmicos, que encontram todos, na dupla de "Satãs" Sharon - Bush, os "símbolos do capitalismo" que desejam destruir, em sonhada regressão ao medievo.

Escavando as raízes do surrealismo brasileiro, seus seguidores assinalaram ainda alguns escritores consagrados: o paranaense Rocha Pombo (18571933), com o romance No hospício (1905); o carioca Raul Pompéia (1863-1895), com a crítica da vida colegial e suas intimidades secretas no belo romance $O$ ateneu (1988); o poeta paraibano Augusto dos Anjos (1884-1914), autor de poemas bem macabros; o carioca Cornélio Pena (1896-1958), com romances e poemas caros à mitopoietica do surrealismo. E, ao lado destes, nomes menos conhecidos, como o da cearense Emília Freitas (1855-1908), cujo "romance psicológico" $A$ Rainha do Ignoto (1899), de trama inusitada, foi considerado pioneiro no gênero fantástico entre nós; ${ }^{17}$ o do baiano (filho de irlandês e de baiana) Pedro Kilkerry (1885-1917), que viveu pobre e morreu tuberculoso em Salvador, sem ter qualquer livro publicado, sendo resgatado por Andrade Muricy, no gigantesco Panorama do Movimento Simbolista Brasileiro (1952), e por Augusto de Campos, em ReVisão de Kilkerry (1970); Adelino Magalhães (1887-1969), autor de A hora veloz (1926), considerado um super-realista pelo crítico Eugenio Gomes ao descrever o bas fond das classes pobres de maneira perturbadora, empregando o monólogo interior a James Joyce (mas não antes dele, como afirmou o crítico); Albertina Bertha

16. http://www.secrel.com.br/jpoesia/lclima.html

17. Ver: FREITAS, 2003; e também: <http://www.amulhernaliteratura.ufsc.br/ catalogo/emilia_vida.html>. 
(1880-1953), autora de romances deliciosamente histéricos, como Exaltação (1922) e Voleta (1926); ${ }^{18}$ o poeta simbolista catarinense Ernani Rosas (1886-1955), cuja vasta produção permaneceu inédita até recentemente, quando, após o trabalho de diversos pesquisadores em arquivos, Augusto de Campos resgatou-o em $O$ enigma Ernani Rosas (1990); e Pedro Dantas (1904-1977), autor desse estranho poema sadomasoquista que é A cachorra:

\section{[...]}

E tais surras de chicote

Me deu, que a cada lambada

Minh'alma perto da morte,

Só a morte desejou;

Meu rosto esfregou na lama,

As faces me babujou

E quando, à atroz azáfama,

O meu olhar se turvou,

Vencido, entregue, arquejante

- Perdido o sangue das veias -

Na praia, sobre as areias,

Meu corpo exausto rodou.

Ah! Pobre corpo do amante

Que até o fim se humilhou!

Então um riso infamante

As faces the escancarou,

Zombou da minha tolice:

— "Eu sou a Cachorra", disse,

"Tu me chamaste: aqui estou."

A essa voz dissiparam-se as sombras

E enquanto ela me mastigava os últimos restos da memória

Senti que da sua boca nasciam rosas

E vi que o céu se rasgava para a maravilhosa aparição. ${ }^{19}$

18. Voleta assim se inicia: "A sentir a nostalgia da noite que se approximava, nimbada de crepúsculos azoinantes, Voleta de Andreia dizia a meia vóz emquanto apanhava as flôres de ipê que tombavam lentas, merencorias, uma a uma: 'Assemelham-se á humanidade... sacearam-se de azul, de irreverencias, de brisas amorosas e não quizeram mais ser...'. Depois de uma pausa: 'Céus, há quanto tempo meus lábios se não esvaem sobre outros labios...". BERTHA, 1926, p. 9.

19. http://www.blocosonline.com.br/literatura/poesia/p99/p991745.htm 
Para o surrealismo brasileiro é resgatada ainda a carioca Gilka Machado (1893-1980), que publicou seu primeiro livro de poesia, Cristais Partidos, em 1915, sendo seus versos considerados escandalosos à época pelo marcado erotismo que continham, levando-a a ser considerada por Péricles Eugênio da Silva Ramos $a$ maior figura feminina de nosso simbolismo. ${ }^{20}$ Mas não é geralmente mencionado o cearense Adolpho Caminha (1867-1897), que morreu jovem, de tuberculose, e cujo romance Bom-crioulo chocou a sociedade com a descrição do desejo homossexual entre marinheiros; também é pouco citado o carioca Lima Barreto (1881-1922), cujos romances Recordações do escrivão Isaías Caminha (1909), O triste fim de Policarpo Quaresma (1915) e Vida e morte de M. J. Gonzaga de Sá (1919) arrasam mitos sociais e nacionais vigentes até hoje.

Ao historiar o surrealismo no Brasil, Sergio Lima perde o entusiasmo ao aproximar-se dos modernistas: exalta apenas Ascânio Lopes (1906-1929), poeta do grupo Verde, de Cataguazes, que morreu aos 23 anos de tuberculose, desprezando os consagrados Aníbal Machado (1894-1964), Emiliano Di Cavalcanti (1897-1976), Flávio de Carvalho (1899-1973), Ismael Nery (1900-1934), Manuel Bandeira (1886-1968), Murilo Mendes (1901-1975), Oswald de Andrade (18901954), Raul Bopp (1898-1984), Tarsila do Amaral (1886-1973) e Vicente do Rego Monteiro (1899-1970). Lima passa em silêncio os nomes de Carlos Drummond de Andrade (1902-1987), Cecília Meireles (1901-1964), Mário de Andrade (18931945), Menotti Del Picchia (1892-1988) e Ronald de Carvalho (1893-1935).

Os modernistas não são bem vistos pelos militantes do surrealismo, quando, forçoso é reconhecê-lo, são dos nossos mais autênticos e talentosos surrealistas. Sergio Lima ainda não publicou seu anunciado "levantamento do surrealismo no Brasil”, mas talvez a ausência de menções mais enfáticas aos modernistas em suas publicações deva-se ao fato de que o modernismo comprometeu-se com o nacionalismo. Internacionalista empedernido, Lima prefere valorizar o surrealismo tardio que ele próprio fundou com a benção de André Breton em 1965, após um profícuo contato com o grupo surrealista francês, chegando ao exagero de afirmar que "o modernismo, com sua bandeira nacionalista, trazia as implicações do totalitarismo na sociedade e na cultura, herdado ou não".

Contudo, apesar das preocupações nacionalistas de nossos modernistas, que às vezes descambaram para o dogmatismo cultural encampado

20. As Poesias Completas de Gilka Machado foram editadas em 1978.

21. MARTINS, 2001, p. 36. 
pelo Estado Novo, não podemos entender o modernismo apartado das vanguardas européias - do futurismo, do dadaísmo, do expressionismo e do surrealismo. Também a cultura norte-americana, através da poesia libertária de Whalt Whitman, ${ }^{22}$ do automóvel, do jazz e do cinema, exerceu grande influência sobre nossos modernistas. Como observou Beatriz Resende,

no início do século, Olavo Bilac condenava, na revista Kosmos, que um dos jornais mais sérios da cidade chegasse a "aconselhar que imitemos os ianques práticos e comodistas, os quais, nos dias de canícula, perambulam pelas ruas de New York e Chicago, em mangas de camisa, com o colete desabotoado, e trazendo o paletó dobrado ao braço, à guisa de sobretudo... concluindo que percorrer a avenida em mangas de camisas "é uma indecência". Mas em 1922 o gosto já estava bem diferente. O cinema e as jazz bands aparecem como principais atrações das novas tendências americanizadas. O acadêmico Graça Aranha defende o cosmopolitismo e sai do Rio para abrir a Semana de Arte Moderna em São Paulo. ${ }^{23}$

O modernismo bebeu em todas as fontes. Quer seus representantes tenham evitado reconhecê-lo no intuito de forjar "do nada" um movimento "autenticamente brasileiro", quer o tenham reconhecido, sem destacar a influência dos diversos grupos da Avant Garde, mesmo negada ou assumida, denegada ou disfarçada, brandida ou omitida, as correntes européias da renovação estética marcaram nossos afrancesados modernistas. Basta lembrar que Oswald de Andrade escreveu suas primeiras peças em francês. ${ }^{24}$ Os modernistas haviam tomado contato com os futuristas, dadaístas, expressionistas e surrealistas in loco, em suas freqüentes viagens à Europa, e especialmente a Paris. A despeito de seu propalado nacionalismo, nosso modernismo deve ser entendido como um magma de todas as vanguardas modernas, assimiladas pela sensibilidade devoradora, canibal, dos intelectuais brasileiros formados ou informados nas grandes capitais da Europa e dos Estados Unidos; magma esse adaptado, depois de assimilado, às nossas

22. Leiam-se os entusiásticos ensaios que Aníbal Machado escreveu sobre o poeta da democracia em MACHADO, 1994, p. 120-138.

23. RESENDE, 1999, p. 14.

24. Ver: MAGALDI, 2004, p. 35-65. 
paisagens e climas, às nossas características sociais e urbanas, aos nossos mitos culturais regionais e nacionais. E o núcleo deste magma está composto, sem dúvida nenhuma, pelos brocados, ouropéis, gemas e cristais de nosso renegado simbolismo.

Resumé: La critique littéraire nie ou minimise l'existence d'une littérature surréaliste brésilienne, en depis du fait de ce que la littérature moderniste soit une relecture des avant-gardes europeénnes. De son côté, afin de faire ressauter son propre nationalisme, les modernistes renient leurs sources européennes à la faveur du folklore native. Ainsi donc, dans son internationalisme militant, nos surréalistes méprisent les modernistes (nos premiers surréalistes) e ne revendiquent pas activement (à la différence de ce qui ont fait les surréalistes européeans) la tradition revolutionaire du symbolisme. Pour recupérer le modernisme pour le surréalisme on doit le rédimensioner dans la tradition des avant-gardes européennes, opération qui se complète avec la rédecouverte de notre symbolisme comme sa source la plus pure.

Mots-clés: modernisme, surréalisme, symbolisme, avant-garde, idéologie.

\section{Referências Bibliográficas}

BRASIL, Ubiratan. Qorpo Santo. Disponível em: <http://www.secrel.com.br/jpoesia/ qsanto.html\#inicio>. Acesso em: 15 mar. 2005.

COSTAllat, Benjamin. Mademoiselle Cinema. Rio de Janeiro: Casa da Palavra, 1999.

CRUZ E SOUZA. Obras completas. Rio de Janeiro: Aguilar, 1995.

DANIEL, Claudio. A poética sincrônica de Sousândrade. Disponível em: <http:// planeta.terra.com.br/arte/PopBox/cdsousandrade.htm>. Acesso em: 15 mar. 2005.

DANTAS, Pedro. A cachorra. Disponível em: <http://www.blocosonline.com.br/ literatura/poesia/p99/p991745.htm>. Acesso em: 15 mar. 2005.

DUARTE, Constância Lima. Emília Freitas. Disponível em: <http:// www.amulhernaliteratura.ufsc.br/catalogo/emilia_vida.html>. Acesso em: 15 mar. 2005.

FRAGA, Eudinyr. Qorpo-Santo: surrealismo ou absurdo? São Paulo: Perspectiva, 1988.

FREITAS, Emília. A rainha do ignoto: romance psicológico. Atualização do texto, introdução e notas de Constância Lima Duarte. Santa Cruz do Sul: Mulheres \& EDUNISC, 2003.

LIMA, Luiz Costa. Um poeta inexistente: Sousândrade. Disponível em: <http:// www.secrel.com.br/jpoesia/lclima.html>. Acesso em: 15 mar. 2005.

LOBO, Luiza. Tradição e ruptura: o Guesa de Sousândrade. São Luís: Edições Sioge, 1979 . 
LUNA, Jayro. Orfeu Spam 14. Jornal Eletrônico de Poesias e Artes. Disponível em: <http://www.jayrus.art.br/index14.html>. Acesso em: 15 mar. 2005.

MACHADO, Aníbal. Parque de diversões. Edição organizada por Raúl Antelo. Belo Horizonte: Editora da UFMG, 1994.

MAGALDI, Sábato. Teatro da ruptura: Oswald de Andrade. São Paulo: Global, 2004.

MARTINS, Floriano. O começo da busca: o surrealismo na poesia da América Latina. São Paulo: Escrituras, 2001.

QORPO-SANTO. Eu sou a vida; eu não sou a morte. Disponível em: <http:// www.biblio.com.br/Templates/qorposanto/meusouavida.htm>. Acesso em: 15 mar. 2005.

QORPO-SANTO. Poemas. Organização de Denise Espírito Santo. Rio de Janeiro: Contra Capa Livraria, 2000.

QORPO-SANTO. Teatro completo. Apresentação de Eudinyr Fraga. São Paulo: Iluminuras, 2001.

RESENDE, Beatriz. A volta de Mademoiselle Cinema. In: COSTALLAT, Benjamin. Mademoiselle Cinema. Rio de Janeiro: Casa da Palavra, 1999. Introdução.

SARTRE, Jean-Paul. Orfeu negro. In: Reflexões sobre o racismo. São Paulo: Difel, 1968.

STEGAGNO-PICCHIO, Luciana. História da literatura brasileira. Rio de Janeiro: Aguilar, 1997.

WILLER, Cláudio. Surrealismo no Brasil: rebelião e imagens poéticas. Disponível em: <http://www.revista.agulha.nom.br/ag27willer.htm>. Acesso em: 15 mar. 2005. 